досвіду і майстерності, готовності до інновацій у власній професійній діяльності засобом активної участі в інтерактивному навчанні та впровадженні технологій.

Підсумовуючи сказане, зазначимо, що рефлексію слід сприймати як форму активного особистісного переосмислення людиною того чи того змісту своєї індивідуальної свідомості. Рефлексивна культура $\epsilon$ особистісним інтегративним утворенням, структура якого охоплює сукупність знань, умінь і здібностей, які реалізуються педагогом через спеціальні дії, спрямовані на виявлення, оцінку й узагальнення найбілыш істотних ознак педагогічного процесу задля досягнення його якісних змін професійного й особистісного вдосконалення.

Формування і розвиток рефлексивної культури має стати першочерговою задачею діяльності андрагогічних служб різних рангів. Підняття на високий рівень психологопедагогічної і методичної підготовки вихователів дошкільних навчальних закладів надасть змогу педагогам поєднувати в собі професіоналізм і гнучкість мислення, винахідливість, упевненість у своїй самобутності і розвинуту інтуїцію, творчу уяву, критичну самооцінку i прагнення, здатність до постійного саморозвитку й самовдосконалення, готовність до реального впровадження новітніх технологій у практику своєї роботи.

\title{
Література
}

1. Акмеологія шкільної освіти: [наук.-метод. посіб.] / за заг. ред. Г. С. Сазоненко. К. : Основи, 2010. - 560 с. 2. Гавриш Н. Зрозуміти іншого, щоб наблизитися до себе / Н. Гавриш, В. Желанова // Вихователь-методист. - 2009. - №6. - С. 7-13. 3. Групові форми методичної роботи з педагогами в сучасному дошкільному закладі / за заг. ред. К. Л. Крутій. - ТОВ «ЛІПС» ЛТД, 2004. - 144 с. $\quad$ 4. Манилюк Ю. С. Шляхи удосконалення управлінської діяльності керівника дошкільного навчального закладу. Актуальні проблеми психології. T. IV : Психолого-педагогічні основи розвитку особистісного потенціалу дитини в сучасному суспільстві : зб. наук. ст. / за заг. ред. проф. С. Д. Максименка та канд. психол. наук С. О. Ладивір. - Київ, 2006. - С. 172-241. 5. Піроженко Т. О. Особистість дошкільника : перспектива розвитку : [навч.-метод. посіб.] / Т. О. Піроженко. - Тернопіль : Мандрівець, 2010. - 136 с. 6. Поніманська Т. І. Дошкільна педагогіка : [навч. посіб. для студ. вищих навч. закладів]/ Т. І. Поніманська. - К. : Академвидав, 2004. - 456 с.

\section{СУТНІСНІ ОЗНАКИ ІННОВАЦІЙНОГО СЕРЕДОВИЩА ЗАГАЛЬНООСВІТНЬОГО НАВЧАЛЬНОГО ЗАКЛАДУ}

Коновальчук I. I. Сутнісні ознаки інноваційного середовища загальноосвітнього навчального закладу.

У статті розглянуто сутнісні ознаки, структуру, функції і критерії інноваційного середовища загальноосвітнього навчального закладу. Із позицій системного підходу інноваційне середовище визначено як цілісність соціально-психологічних, організаційно-педагогічних, інформаційно-комунікативних, матеріальних, технологічних та інших умов, що в єдності постають засобом стимулювання, підтримки, управління, рефлексії інноваційної діяльності педагогів та їх професійного розвитку. За змістом інноваційне середовище - це сукупність інновацій, що створюють нові можливості для розвитку навчального закладу.

Ключові слова: нововведення, середовище, середовищний підхід, інноваційне середовище навчального закладу, інноваційна діяльність. 
Коновальчук И. И. Сущностные характеристики инновационной среды общеобразовательного учебного заведения.

В статье рассмотрены сущностные признаки, структура, функции и критерии инновационной среды общеобразовательного учебного заведения. C позиций системного подхода инновационная среда определена как целостность социальнопсихологических, организационно-педагогических, информационно-коммуникативных, материальных, технологических и других условий, которые в единстве выступают средством стимулирования, поддержки, управления, рефлексии инновационной деятельности педагогов и их профессионального развития. По содержанию инновационная среда - это совокупность инноваций, которые создают новые возможности для развития учебного заведения.

Ключевые слова: нововведение, среда, средовый подход, инновационная среда учебного заведения, инновационная деятельность.

Konovalchuk I. I. Essential features of the innovative environment in general educational institutions.

The article reviews the essential features of the structure, function and criteria for innovative environment of an educational institution. From the standpoint of systematic approach innovative environment is defined as the integrity of socio-psychological, organizational, educational, informative and communicational, substantial, technological and other conditions that, as a unity, form the means of stimulation, support, management, reflection for the innovative activity of educators and their professional development. As such the innovative environment is a combination of innovations that create new opportunities for the development of educational institution.

Key words: innovation, environment, environmental approach, innovative environment of the institution, innovation.

Сучасні інноваційні загальноосвітні навчальні заклади прагнуть до створення своєї унікальної соціально-педагогічної моделі, яка презентує їх імідж і визначає конкурентні переваги на ринку освітніх послуг. Усе більше дослідників пов'язують розв'язання цього завдання $з$ організацією в освітніх закладах інноваційного середовища, у якому кожен педагог отримує стимули й можливості реалізувати свої творчі ідеї, набути досвіду інноваційної діяльності.

Аналіз досліджень засвідчує, що в педагогічній теорії інноваційне середовище загальноосвітнього навчального закладу розглядається в досить широкому спектрі: як умова розвитку освітньої установи, у якості соціально-психологічної підтримки й формування інноваційної культури, мотиваційної основи інноваційної діяльності педагогів, умови рефлексії i, відповідно, ефективності інноваційної діяльності, інтегрального інструменту, засобу м'якого, «точкового» опосередкованого управління професійним розвитком особистості педагога, фактора професійного саморозвитку педагога, як система професійних і міжособистісних взаємин (В. Баришніков, С. Дерябо, Л. Загрекова, Р. Касіна, А. Каташов, О. Крутенко, В. Лазарев, Ю. Мануйлов, А. Моїсєєв, Н. Нємова, Л. Новікова, С. Поздняков, В. Сєріков, В. Слободчіков, О. Трінітатська, І. Фрумін, Г. Шек, В. Ясвін та ін.).

3 одного боку, така багатоаспектність у трактуванні інноваційного середовища свідчить про його соціокультурну та психолого-педагогічну значущість у розвитку навчального закладу нового типу, з іншого, - про відсутність системного аналізу його сутності й потенціалу в освоєнні та реалізації нововведень. 
Незважаючи на зростання інтересу науковців і практиків до проблеми створення і функціонування інноваційного середовища в загальноосвітньому навчальному закладі, низка питань у цій галузі потребує наукового осмислення. Не сформоване саме поняття «інноваційне середовище», немає єдиного розуміння його сутнісних ознак, структури, не розкриті механізми використання його потенціалу в активізації інноваційних процесів. У реальній практиці таке середовище формується переважно спонтанно, не завжди відповідає ідеям гуманістичної, особистісно-розвивальної парадигми освіти.

Мета статті полягає в системному аналізі сутнісних ознак та потенціалу інноваційного середовища загальноосвітнього навчального закладу як інтегрованого засобу стимулювання, підтримки, управління, рефлексії інноваційної діяльності педагогів та їх професійного розвитку.

Досвід становлення i розвитку навчальних закладів інноваційного типу (В. Сухомлинського, О. Захаренка, М. Гузика, В. Караковського, М. Щетініна, Р. Штейнера, П. Петерсона, С. Френе, Олександрівської гімназії м. Суми, навчальновиховного комплексу «Гімназія імені Лесі Українки - школа I ступеня» м. НовоградВолинського, Володимирецького районного колегіуму та багатьох інших) переконує, що саме створення інноваційного середовища значною мірою зумовило якісні зміни у ставленні педагогів до нововведень й до себе як суб'єктів інноваційного процесу, у трансформації системи цінностей педагогічної діяльності, сприяло вироблення місії та інноваційної стратегії розвитку навчального закладу, створення особливої атмосфери творчого пошуку, корпоративного духу, зняття бар'єрів інноваційної діяльності, розвитку ресурсів навчального закладу.

Методологія середовищного підходу представляє стратегію опосередкованого управління в освіті й розглядає середовище як ключовий засіб розв'язання управлінських задач переведення навчального закладу в інноваційний режим діяльності й розвитку готовності педагогів до освоєння й реалізації інновацій. Середовищний підхід - теорія і технологія управління через середовище процесами формування та розвитку особистості. Основним поняттям підходу $є$ «середовище» як те, серед чого й кого перебуває суб'єкт, у функціональному значенні засобу, за допомогою якого формується його спосіб життя й опосередковується розвиток особистості [7, с. 21].

Оскільки середовище опосередковує формування особистості, то логічним є висновок, що інноваційний тип середовища опосередковує інноваційний спосіб життєдіяльності педагога. Спосіб життя виявляється в стійких формах поведінки людини й є проміжною ланкою між особистістю і середовищем та постає умовою досягнення поставленої мети [4, с. 4].

У цільовому контексті інноваційне середовище $\epsilon$ умовою розвитку загальноосвітнього навчального закладу, формування інноваційного мислення, ціннісних орієнтацій професійної діяльності та інноваційної культури педагогів. Зміст інноваційного середовища - це новий тип професійних, соціальних й особистісних відносин між суб'єктами інноваційного процесу, у яких викристалізовуються перспективи, осмислюється місія діяльності навчального закладу. Змістова частина функціонування інноваційного середовища забезпечується комплексом інноваційних концепцій, програм, проектів. У технологічному плані середовищний підхід представляє собою систему дій суб' єкта із середовищем, спрямованих на діагностику та аналіз його стану, проектування і продукування результатів необхідних нововведень. У процесі взаємодії з інноваційним середовищем відбувається ідентифікація педагога як суб'єкта інновацій - актуалізація потреб, цілепокладання, усвідомлення мотивів, засвоєння норм, способів інноваційної діяльності. Технологічний складник інноваційного середовища охоплює систему форм і методів розвитку інноваційної компетентності педагогів: 
школи новаторства, інноваційні центри, лабораторії, конференції, форуми, творчі групи, майстер-класи, різноманітні тренінги тощо.

У витлумаченні сутності інноваційного середовища загальноосвітнього навчального закладу зазвичай виходять із його провідної функції впливу на ефективність інноваційних процесів і розглядають його як умову, як засіб, як інструмент управління, стимулювання, мотивації, взаємодії педагогів, обміну знаннями й набуття досвіду, інтенсифікації нововведень тощо.

Р. Касіна розширює уявлення про інноваційне середовище, виходячи з розуміння його двоїстої природи: як джерела нових можливостей і як умови їх реалізації у практичній діяльності. Інноваційне середовище $є$ якісно новим станом професійнопедагогічного середовища навчального закладу, що має дуже високий потенціал для його розвитку $[4$, с. 3$]$.

За визначенням І. Дичківської, інноваційне середовище - це педагогічно доцільно організований простір життєдіяльності, який сприяє розвитку інноваційного ресурсу особистості; інтегрований засіб накопичення і реалізації інноваційного потенціалу навчального закладу [2, с. 339].

Саме по собі середовище - даність і не завжди володіє розвивальним впливом. Не факт, що педагог, який перебуває в інноваційному середовищі, спонтанно (іманентно), сам по собі буде освоювати й привласнювати його цінності, розвивати і впроваджувати інноваційні ідеї. Механізмом організації інноваційного середовища $\epsilon$ взаємодія педагогів, творчих ініціативних груп, у процесі якої відбувається обмін знаннями, ідеями, зіткнення й об'єднання інтересів, цінностей, оцінка, переосмислення й збагачення індивідуального й колективного досвіду.

Основним аспектом, за якого інноваційне середовище виконує свої функції, $\epsilon$ наявність можливості знаходження в ньому суб'єктом своїх актуальних індивідуальних смислів і шансів їх реалізації. Розроблена О. Трінітатською теорія управління середовищем інноваційного навчального закладу грунтується на таких поняттях: 1) «середовище інноваційного освітнього закладу»- це організований простір соціально-культурних, предметно-дизайнерських, виховно-навчальних, комунікативнопартнерських i демократично-колегіальних умов, у яких реалізується інноваційна функція школи; 2) «розвивальне середовище інноваційної освітньої установи»- це сукупність цілеспрямовано організованих просторів, континуум яких грунтується на введенні цінних для кожного суб'єкта духовних смислів і можливостей; 3) «дискретні педагогічні інновації» (організаційні форми) - автономні і самостійно значимі елементи, що не потребують глобальної (суцільної) перебудови освітнього процесу, носять тимчасовий і локальний характер [9, с. 14]. Представлена концепція середовища, на відміну від інших, концентрує всі його складники на суб'єктних цінностях, смислах і можливостях, унаслідок чого середовище «оживає», стає дієвим. Середовище - це не тільки сукупність певних об'єктів, а й взаємодія педагогів 3 ними, творча робота 3 їх зміни, у процесі якої відбувається як розвиток середовища, так і професійний та особистісний розвиток педагогів.

Створення інноваційного середовища в навчальному закладі передбачає певну послідовність етапів: 1) моніторинг середовища - виявлення його розвивального потенціалу, вивчення потреб і мотивів його суб'єктів, прогнозування можливих перспектив; 2) розроблення моделі середовища, де пріоритетним має стати моделювання не стільки його об'єктів і суб'єктів, скільки можливих зв'язків і відносин між ними; 3) створення ціннісно-смислової єдності суб'єктів середовища через вироблення місії школи, в основі якої - гуманістичні цінності; 4) вироблення концепції навчального закладу, що відображає його «індивідуальне обличчя», його неповторність, 
визначає стратегію діяльності; 5) організацію взаємодії різних суб'єктів середовища як основи процесу інтеграції, необхідного для його функціонування; 6) створення умов для реалізації кожним суб'єктом середовища своїх індивідуальних перспектив.

Місія, що є головною метою загальноосвітнього навчального закладу як соціальнопедагогічної системи, відбиває суть і його призначення, деталізує статус, репрезентує напрями та орієнтири для визначення цілей та стратегій на різних ієрархічних рівнях управління і відіграє важливу роль під час визначення пріоритетів діяльності. Бачення це взірець, це погляд у власне майбутнє, а також планування, яким воно має бути. Бачення має бути настільки привабливим, що сприятиме колективу натхненно працювати на нього, воно не $\epsilon$ сталим і може бути оцінено та розвинуто через якийсь час, як зміна ресурсів і потреб через наявність необхідної інформації [3, с. 46-47].

Оскільки концепція фактично є місією школи, то, перш ніж намагатися «впливати на суспільство», школа спочатку мусить виробити «єдине бачення власних завдань», визначити свій імідж, «усвідомити власну місію, яка визначає: спільні цінності й погляди, культуру школи; наслідки організації й стилю навчання; процес прийняття рішень...; підтримується всіма людьми, що відповідають за освіту в школі; формулюється таким чином, щоби можна було оцінити, чи була реалізована місія школи та якою мірою» [8, с. 157].

Показниками становлення інноваційного середовища є достатній рівень нових ознак, форм, унаслідок чого відбувається зміна якісного стану навчального закладу, створення відповідних нормативно-організаційних та науково-методичних умов для підтримки соціально-педагогічних ініціатив педагогів, свободи творчості, зростає сприйнятливість до інновацій, виникають додаткові можливості задля реалізації нових ідей.

Як системне утворення інноваційне середовище має власну організаційнофункціональну структуру, основними складниками якої Л. Ващенко визначено: стратегію розвитку освіти, тактику інноваційних процесів, зміст інноваційного середовища, організаційне забезпечення його розвитку, прогнозування розвитку освіти. Кожен із елементів структури, взаємодіючи між собою, наповнює інноваційне середовище своїм спрямуванням змін [1, с. 25]. Необхідно зазначити, що взаємозв'язки 3'являються і діють тільки в процесі активності, взаємодії компонентів середовища, вектор яких спрямований на досягнення цілей педагогічної системи. Сила й характер взаємозв' язків між компонентами відповідає їх функціональній активності в загальній спрямованості інноваційного середовища на підвищення інноваційного потенціалу навчального закладу.

В. Ясвін під час моделювання освітнього середовища інноваційного навчального закладу визначає такі психодіагностичні параметри його експертизи: широта, інтенсивність, модальність, ступінь усвідомлюваності, ступінь стійкості, емоційність, узагальненість, домінантність, когерентність, активність, мобільність [10, с. 114]. Цілеспрямовано регулюючи ці параметри середовища можна змінювати ступінь i напрямок його впливу як на інноваційний процес загалом, так і на його учасників.

На прикладі Сахнівської школи О. Крутенко встановлено, що широта середовища забезпечує високий рівень такої його структурно-динамічної характеристики, як інтенсивність, тобто насиченість різноманітними можливостями та впливами за умови концентрованого їх вияву [6, с. 13].

Під час визначення критеріїв та показників інноваційного середовища ми виходили 3 цілісності його функцій та специфіки впливу на інтенсифікацію інноваційних процесів у навчальному закладі. До них віднесено такі параметри: стратегічна спрямованість на освоєння і реалізацію нововведень; цілісність компонентів та їх взаємодія; домінантність у системі особистісних цінностей суб'єктів у порівнянні 3 
іншими джерелами впливу; широта охоплення суб'єктів інноваційного процесу; гуманізація та естетизація взаємовідносин; високий рівень організованості; природо- і культуровідповідність; інтенсивність інноваційних можливостей і змін; здатність виявляти, ініціювати нові ідеї та забезпечувати їх реалізацію; когерентність узгодженість 3 індивідуальними потребами й смислами його суб'єктів; науковоінформаційна насиченість і комунікативність- можливість обміну знаннями, ідеями, досвідом; відкритість і залучення до загальної інноваційної сфери суспільства; високий ступінь усвідомлюваності середовища і вмотивованість його суб'єктів, що передбачає особистісну відповідальність кожного за спільну діяльність; особистісна детермінованість як можливість і здатність педагогів впливати на середовище, змінювати його; емоційна насиченість, атмосфера оптимізму; наявність хаосу як ситуації виведення традиційної педагогічної системи з стану стабільності, рівноваги й початку творчих і конструктивних процесів саморозвитку.

Зокрема зауважимо, що, на думку О. Захаренка, раціональний компонент не повинен бути домінуючим у середовищі. Наявність емоційного компонента викликає у суб'єктів середовища особистісний інтерес і неформальне ставлення, оскільки саме емоційний акцент суб'єкт-суб'єктних стосунків та суб'єкт-об'єктних ставлень надає середовищу певної привабливості [6, с. 13].

Управління розвивальним середовищем передовсім спрямоване на розвиток професіоналізму вчителів та здійснюється за допомогою зміни функцій внутрішкільного управління, а саме: 1) інформаційно-аналітична функція (визначає динаміку професійної позиції вчителів, педагогічного мислення та рефлексії); 2) планово-прогностична функція (стимулює розвиток педагогічного цілепокладання та прогнозування); 3) організаційно-виконавська функція (зумовлює взаємообмін педагогічним досвідом у колективі, активізацію професійної самоосвіти); 4) контрольно-діагностувальна функція (сприяє формуванню відповідальності та компетентності, розвитку самоорганізації, осмисленню власної діяльності) [9, с. 15].

Структура інноваційного середовища визначається функціональною значимістю кожного 3 його компонентів в активізації інноваційних процесів у навчальному закладі. Узагальнюючи різні підходи, ми визначаємо такі складники інноваційного середовища загальноосвітнього навчального закладу: стратегічно-цільовий, емоційно-ціннісний, соціокультурний, соціально-психологічний, організаційно-педагогічний, інформаційнокомунікативний, матеріальний, технологічний.

Ключовою сутнісною характеристикою інноваційного середовища $є$ інноваційність його складників. Інноваційність $€$ ознакою й основним механізмом динамічного саморозвитку середовища навчального закладу, показником його відкритості й готовності до змін, можливості освоєння й реалізації нововведень.

Отже, інноваційне середовище сучасного загальноосвітнього навчального закладу $\epsilon$ складною динамічною системою й визначається як цілісність соціальнопсихологічних, організаційно-педагогічних, інформаційно-комунікативних, матеріальних, технологічних та інших умов, що в єдності постають засобом стимулювання, підтримки, управління, рефлексії інноваційної діяльності педагогів та їх професійного розвитку. За змістовою характеристикою інноваційне середовище освітнього закладу - це сукупність нововведень, що створюють нові можливості для розвитку навчального закладу й професійної самореалізації педагогів. Концептуальною ідеєю розвитку інноваційного середовища $є$ відкритість до інновацій, визнання їх ключового значення в його структурі, що й визначає рівень інноваційного потенціалу навчального закладу.

Перспективи подальших досліджень полягають у виявленні механізмів впливу 
інноваційного середовища на формування інноваційного потенціалу навчального закладу й способів самореалізації педагогів.

\section{Література}

1. Ващенко Л. М. Система управління інноваційними процесами в загальній середній освіті регіону : автореф. дис. ... д-ра пед. наук: 13.00.01 / Л. М. Ващенко. - К., 2006. - 45 с. 2. Дичківська І. М. Інноваційні педагогічні технології: [навч. посіб.]/ I. М. Дичківська. - К. : Академвидав, 2004. - 352 с. 3. Калініна Л. М. Інформаційне управління загальноосвітнім навчальним закладом: системи, процеси, технології: [монографія]/ Л. М. Калініна. - $\quad$ К. : $\quad$ Інформатор, 2008. - 472 с. 4. Кассина Р. С. Инновационная среда образовательного учреждения как интегральное средство профессионального развития учителя: автореф. дис. ... канд. пед.. наук : 13.00.08 / Р. С. Кассина. - Нижний Новгород, 2006. - 24 с. 5. Каташов А. І. Педагогічні основи розвитку інноваційного освітнього середовища сучасного ліцею: автореф. дис....канд. пед. наук: 13.00.01/ А. І. Каташов. - Луганськ, 2001. - 22 с. 6. Крутенко О. В. Виховання гуманістичних цінностей школяра у педагогічній спадщині О. А. Захаренка: автореф. дис.... канд. пед. наук: 13.00.01 / О. В. Крутенко. - ПереяславХмельницький, 2012. - 24 с. 7. Мануйлов Ю. С. Концептуальные основы средового подхода в воспитании / Ю. С. Мануйлов // Вестник Костромского государственного университета им. Н. А. Некрасова. - Т. 14. Серия: «Педагогика. Психология. Социальная работа. Ювенология. Социокинетика». - 2008. - № 4. - С. 21-27. 8. Саранов А. М. Инновационный процесс как фактор саморазвития современной школы: методология, теория, практика: [монография] / А. М. Саранов. - Волгоград : Перемена, 2000. - 259 с. 9. Тринитатская О. Г. Управление развивающей средой инновационного образовательного учреждения : дис. ... докт. пед. наук : 13.00.01 / О. Г. Тринитатская. Москва, 2009. - 512 с. 10. Ясвин В. А. Образовательная среда: от моделирования к проектированию: [монография] / В. А. Ясвин. - М. : Смысл, 2001. - 365 с.

\section{НАВЫК ПОСТРОЕНИЯ КОРРЕКТНОЙ СИТУАЦИОННОЙ ОСОЗНАННОСТИ В СТРУКТУРЕ ПРОФЕССИОНАЛЬНОЙ НАЛЁЖНОСТИ ЛЁТНОГО СОСТАВА}

Кушнір О. О. Навичка будування коректної ситуаційної усвідомленості у структурі професійної надійності льотного складу.

У статті наводиться обгрунтування необхідності розроблення та впровадження нових педагогічних підходів до підготовки майбутніх пілотів, а саме навчання побудові коректної ситуаційної усвідомленості. Аналізується поняття «ситуаційна усвідомленість», іiї сутність, алгоритм формування й значення для професійної надійності льотного складу.

Ключові слова: майбутні пілоти, професійна надійність, нетехнічні навички, індивідуальний стиль діяльності, управління психічною діяльністю, ситуаційна усвідомленість, образ польоту.

Кушнир О. А. Навык построения корректной ситуационной осознанности в структуре профессиональной надёжности лётного состава.

В статье приводится обоснование необходимости разработки и внедрения новых педагогических подходов к подготовке будущих пилотов, а именно обучения построению корректной ситуационной осознанности. Анализируется понятие 